\title{
A máj és az immunrendszer
}

\author{
Jakab Lajos dr. \\ Semmelweis Egyetem, Általános Orvostudományi Kar, III. Belgyógyászati Klinika, Budapest
}

\begin{abstract}
A máj köztudottan a szervezet anyagcsereközpontja, centrális regulátora központi idegrendszeri irányítás alatt. Ugyanakkor sejtes szöveti szerkezete, felépítése és nem utolsósorban anatómiai lokalizációja predesztinálják, hogy a szervezet épségének védelmében az immunrendszer integráns tagjaként egyedi szerepet birtokoljon. A szöveti szerveződés meghatározója a sinusoid rendszer. Ennek kialakításában a hepatocyták mellett az egysoros sinus endothelium, ennek külső felszínéhez közel a stellatasejtek, belső felszínén a Kupffer-sejtek tömege, a dendritikus, valamint egyéb sejtféleségek találhatók (T- és B-lymphocyták, természetes ölősejtek, mastocyták, granulocyták). Az immunsejtek sokfélesége és sokasága biztosítja a szervezetet károsító tényező́k maradéktalan elhárítását, ami nem mindig jár teljes sikerrel. Így válhat a máj az immunrendszert felépítő szövetek koherens részévé. A májban az immunsejtek sajátos aktivált állapotban léteznek, szoros, folyamatos kooperációban. A legtöbb feladat fóként a haemopoeticus sejtek és döntően a transzformáló növekedési faktor- $\beta$ révén a perifériás immuntolerancia biztosítása. A máj meghatározó módon vesz részt a szervezet nem specifikus immunvédekezésében. Ennek döntő módja az úgynevezett akutfázis-reakció, valamint a szervezet specifikus, adaptív immunválaszának alakítása. A föszerepen belül a funkció úgy alakul, hogy a T- és B-lymphocyta-aktivitás retardálódása mellett immunglobulin-képzés, szekréciógátlás érvényesül a transzformáló növekedési faktor- $\beta$ közremúködésével. Kivétel az IgA-képzés és -átkapcsolás segítése. Az összes többi Ig és Ig-alosztály hatására a be- és átkapcsolás gátlódik. Az IgA-szekréció helye meghatározó módon a bélrendszer. Különösen szembetűnő az úgynevezett akutfázis-reakcióban való központi irányító tevékenység, amit a cortico-hypothalamo-hypophysis-mellékvese tengely vezérel. A szervezet harmonikus múködését a sejtes elemeken túl a hormonok, adhéziós molekulák, kemokinek, citokinek összehangolt tevékenysége garantálja. Ebben központi szerep jut az akutfázis-reaktánsoknak. A humán szervezetben az a2-makroglobulin koncenctrációja a vérben csak mérsékelt emelkedést mutat, szerepe mégis beépül az elhárító válaszba. Ennek egyik módja a transzformáló növekedési faktor- $\beta$-val való kapcsolatrendszer. A transzformáló növekedési faktor- $\beta$ rendkívüli széles körben ható centrális citokin, amely fontos szereppel bír a máj és az egész organizmus inflammációs folyamataiban, az immuntolerancia kiépítésében. A szervezetben a perifériás immuntolerancia folyamata tehát a lymphocytaproliferáció, -differenciálódás és túlélés szoros szabályozása révén valósul meg. Orv. Hetil., 2015, 156(30), 1203-1213.
\end{abstract}

Kulcsszavak: máj, immunrendszer, perifériás immuntolerancia, a2-makroglobulin, transzformáló növekedési faktor

\section{The liver and the immune system}

The liver is known to be the metabolic centre of the organism and is under the control of the central nervous system. It has a peculiar tissue structure and its anatomic localisation defines it as part of the immune system having an individual role in the defence of the organism. The determinant of its particular tissue build-up is the sinusoid system. In addition to hepatocytes, one cell row "endothelium", stellate cells close to the external surface, Kupffer cells tightly to its inner surface, as well as dendritic cells and other cell types ( $\mathrm{T}$ and B lymphocytes, natural killer and natural killer T-cells, mast cells, granulocytes) are present. The multitudes and variety of cells make it possible to carry out the tasks according to the assignment of the organism. The liver is a member of the immune system having immune cells largely in an activated state. Its principal tasks are the assurance of the peripheral immune tolerance of the organism with the help of the haemopoetic cells and transforming growth factor- $\beta$. The liver takes part in the determination of the manner of the non-specific immune response of the organism. In addition to acute phase reaction of the organism, the liver has a role in the adaptive/specific immune response. These functions include retardation of the $\mathrm{T}$ and $\mathrm{B}$ lymphocytes and the defence against harmful pathogens. With the collaboration of transforming growth factor- $\beta$, immunoglobulins and their subclasses are inhibited just as the response of the T lymphocytes. The only exception is the undisturbed immunoglobulin A production. Particularly important is the intensive participation of the liver in the acute phase reaction of the organism, which is organised and guided by the coordinated functions of the cortico-hypothalamo-hypophysis-adrenal axis. Beside cellular elements, hormones, adhesion molecules, chemokines and cytokines are also involved in the cooperation with the organs. Acute phase reactants play a central role in these processes. Until recently the $\alpha 2$-macroglobulin was not considered as an acute reactant of the organism, but it is now functionally included in the acute phase reaction presumably due to its close connection with the trans- 
forming growth factor- $\beta$. Transforming growth factor- $\beta$ has extraordinarily important roles in all phases of inflammation and in the specific immune response. The peripheral immune tolerance of the organism involves tightly coupled regulation of proliferation, differentiation and survival of lymphocytes.

Keywords: liver, immune system, peripheral immune tolerance, $\alpha 2$-macroglobulin, transforming growth factor

Jakab, L. [The liver and the immune system]. Orv. Hetil., 2015, 156(30), 1203-1213.

(Beérkezett: 2015. április 16.; elfogadva: 2015. május 24.)

\section{Rövidítések}

$\alpha 2 \mathrm{M}=\alpha 2$-makroglobulin; $\mathrm{Ag}=$ antigén; APR = akutfázisreaktáns; APRE = STAT-responsive element; APRS = akutfázisreakció szindróma; $\mathrm{BMP}=$ bone morphogenetic protein; $\mathrm{CNF}=$ ciliaris neurotrophicus faktor; $\mathrm{CRP}=\mathrm{C}$-reaktív protein; $\mathrm{CT}=$ cardiotrophin $; \mathrm{D}=$ dendritikus sejt $\mathrm{EGF}=$ epidermalis növekedési faktor; GP = glikoprotein; HDL = high-density lipoprotein; HGF = hepatocytanövekedési faktor; HR-GP = hisztidingazdag GP; IFN- $\gamma=$ interferon- $\gamma$; IL-1 = interleukin-1; $\mathrm{LAP}=$ latenciaasszociált protein LIF $=$ leukaemiainhibitor-faktor; LPS = lipopoliszacharid; LRP $=$ low-density lipoprotein related protein; $\mathrm{LTBP}=$ latent $\mathrm{TGF}-\beta$ binding protein; $\mathrm{Ma}=$ macrophag; $\mathrm{MD} 2=$ myeloiddifferenciáló faktor; $\mathrm{NF}-\kappa \mathrm{B}=\mathrm{p} 65$ konstituenssel kapcsolt molekuláris kappa-B; NK-sejt = természetes ölősejt; PAMP = patogénasszociált molekuláris mintázat; $\mathrm{PDGF}=$ platelet-derived growth factor; $\mathrm{PG}=$ proteoglikán; $\mathrm{PRP}=$ patogénfelismerő receptor; $\mathrm{PRR}=$ pattern recognition receptor; SOCS $=$ szuppresszív citokin jel; STAT $=$ signal transducer and activator of transcription; TGF- $\beta=$ (transzformáló növekedési faktor- $\beta$; TLR = Toll-szerü receptorok; TNF- $\alpha=$ tumornekrózis-faktor- $\alpha$

A májszövet egyedi volta, szerkezeti felépítése, vérkeringési különlegessége sajátos funkciók elvégzését teszi lehetővé. A máj a humán szervezet legnagyobb szerve. Vérellátása kettős; az artériás vér tömérdek, az individuum életmúködését biztosító alakos, molekuláris, biokémiai anyagokat tartalmaz, míg a másik gastrointestinalis rendszer nagy mennyiségű vénás vérét szállítja és a vena portaen keresztül jut a májba. Az artériás és vénás vér összekeverődve a vena hepaticán át a vena cava inferiorba, a jobb szívfélbe, a tüdőbe, majd vissza a bal szívfélbe jut. A két fő forrásból eredő vér $80 \%$-a a lépból és az intestinumból ered. Egyre gyúlnek, szaporodnak a májjal, a májban található immunrendszerrel összefüggő adatok és ismeretek.

\section{Szerkezet és utalás a funkcióra}

A máj egyedi szöveti felépítését a sinusoid rendszer határozza meg. A sinusoidokat a hepatocyták határolják. Az így kialakult csatornákban a sinusoid rendszerbeli endothelium egy sejtrétegű hám nem hermetikusan lezárt teret képez. Ennek külső felszínéhez közel a hepatocyták sorai találhatóak. Az úgynevezett stellatasejtek (Ito-sejt, lipocyta) a hepatocyta-endothelium résben (Disse-tér), míg az endothelium belső felszínéhez simulva a sajátos macrophagok (Ma), a Kupffer-sejtek, valamint a plasmacytoid dendritikus (D) sejtek találhatóak. A májban fellelhető Kupffer- és D-sejtek az organizmus Ma-menynyiségének $80 \%$-át teszik ki, részben periportalis elrendeződésben. Konszolidált állapotban a teljes májsejtmennyiség 15\%-át reprezentálják. Ezen sejttömeg főbb funkciói a phagocytosis, antigén- (Ag-) prezentálás, kemokin- és citokintermelés.

A májban az artériás és a vena portae szállította vér mennyisége $1500 \mathrm{ml} / \mathrm{min}$, ennek körülbelül 80\%-a ered a lépből és az intestinumból. Ebben a vértömegben jut be a májba az oxigén mellett az artériás és vena portae vérben fellelhető alakos és molekuláris, a funkcióhoz nélkülözhetetlen „nyersanyag”. Itt történik a szénhidrátok, fehérjék és lipidek regulált metabolizmusa, az endogén metabolitok, xenobiotikumok biotranszformációja, detoxikálása, valamint az egyed fennmaradásához nem nélkülözhető, vérbe jutó alkotórészek nagyobb hányadának a bioszintézise. Fontos feladat a szervezeti homeosztázis fenntartása. Itt termelődik az epe, történik az epesavak sódependens felszívódásának előkészítése, az epesavak által lehetővé vált metabolitok exkréciója. Elidegeníthetetlen tevékenysége a májnak a szervezeti immunrendszerbe történő beilleszkedés. Ezek között kiemelkedő egyedi, szervezeti akutfázis-reakció (APRS) generálása, azaz a természetes, majd az adaptív szervezeti immunválasz alakítása. A lépból és a bélrendszerből a májba jutó anyagok immunológiai jelmolekulák tömegének a fogadása, a válaszok kimunkálása. A már vázolt szerkezeti májsejttípusokon túl találhatóak itt lymphocyták (T, B), natural killer (NK) sejtek, NK T-lymphocyták, monocyták, fibroblastok, mastocyták, valamint az igen aktív kötőszöveti (interstitialis) alapállomány. A sejtek többsége speciális, úgynevezett tolerogén alakban van jelen, ami a szervezeti immuntolerancia biztosítéka egyben. Az egész szervezet strukturális, funkcionális egységének és épségének biztosítéka az exogén átültetett májszövet megmaradásának. A kötőszöveti alkatrészek döntő részben fibroblastok, stellatasejtek és transzdifferenciált májsejtek termelvénye. A stellatasejtek mellett transzdifferenciálódásra képesek az endotheliumsejtek, de a hepatocyták is. Az új sejtalakzatok képesek mátrixalkatrészek, proteoglikánok (PG), glikoproteinek (GP) szintézisére $[1,2,3,4,5]$. 


\section{A máj immunológiai szerepe}

A már említett Kupffer- és Ma-sejtek mellett találhatóak még plasmocytoid, myeloid D-sejtek és sinus endothelium. Ag-bemutatásra az endothelium és a hepatocyták is képessé válnak. A májbeli sejteken található úgynevezett patogénfelismeró receptorok (PRP) szolúbilis alakban is találhatóak és felismerik a patogénasszociált molekuláris mintázatot (PAMP). A felismerést követően a kórokozó szignáltranszducer-aktivátor (STAT 3) a p65 konstituenssel kapcsolt molekuláris kappa-B (NF- $\mathrm{BB})$ kemokinek és citokinek képzését indítja be, amelyben a Toll-féle receptorok (TLR), az inflammasomák és nem utolsósorban az itt keletkező GP-k, PG-k, fehérjék vesznek részt. A jelutak építőit transzkripciós faktorok ténykedése jellemzi. A funkcionális tényezők között az aktív folyamatok szereplőiként TRL4+CD4ly+MD2 (myeloiddifferenciáló faktor) inflammasomaszerkezet testesül meg. A májban a sessilis immunsejteknek az immuntolerancia létrehozásában, fenntartásában van alapvető szerepük. Ebben meghatározó szerepet kap a májbeli tolerogén környezet. Ez az egyén fennmaradásának alapja. Élettani viszonyok mellett a stellatasejtek A-vitamint, zsírokat tárolnak. Károsodás bekövetkezte, például infekció esetén elvesztik azokat, és más, már említett sejttípusokkal egyetemben transzdifferenciálódás után Ag bemutatására válnak képessé $[2,3,6]$.

Szinte neológ immunszövetként funkcionál a teljes májsejtapparátus. A transzdifferenciálódás lényege, hogy a TGF- $\beta$ (transzformáló növekedési faktor- $\beta$ ) és a platelet-derived growth factor (PDGF) hatására a sejtek rokonítható sejtekké differenciálódva funkciót váltanak. Így a kötőszövet-fibrosis kialakulásának alapjává válnak. Ez annyira együtt halad az intrahepaticus folyamatokkal, hogy a hepatocytapusztulás, makroszerkezeti átépülés a fibrosis (krónikus gyulladás) mércéjeként tükrözik a folyamat stádiumait. Így például a hyaluronan, hyaluronectin, fibronectin mennyiségi változásai a vérben alkalmasak az intrahepaticus folyamatok nyomon követésére. A kollagén rostképződés az I > II > IV típusú kollagén rostmintázat szerint halad előre, és az I-es típusú dominancia már irreverzíbilis stádiumra utal. A bélrendszeri baktériumok tömegeinek metabolikusan aktív anyagcsere-származékai jutnak be a sinusokba, de bejuthatnak maguk a baktériumok is. Ilyen anyag például a lipopoliszacharid (LPS). A vena hepatica vérben baktérium, az LPS nincs konszolidált helyzetben, míg a vena portae vérben körülbelül $1 \mathrm{ng} / \mathrm{ml}$ LPS található. Ezen „vendég” anyagok között a patogén vagy nem patogén elemek felismerése, elkülönítése után a patogén anyagok eliminálódnak. A májban a már említetteken túl, védekező anyagok, mint például komplementkomponensek, lektinek, pentraxinok, akutfázis-reaktánsok (APR), kemokinek és citokinek sokasága keletkezik. A citokinek az elhárító válaszok irányítói. Beindítják a szervezeti nem specifikus védekező választ, a naturális immunválaszt, az inflammatiót és a specifikus, adaptív immunválaszt.
A kórokozókat a PAMP, az immunsejtek felismeróképessége révén azonosítja a máj. A védelmi rendszerek károsodása, sérülése kóros következményekhez vezet. Így például a belekben dysbacteriosis alakul ki, ami rontja az élettani funkciót. A májban vagy más szervben zajló kórfolyamat ellen nem specifikus immunválasz, gyulladás alakul ki. Ennek elindítása, lefolyása az egész szervezet részvételével, a központi idegrendszer vezénylete mellett történik. Vannak nem specifikus, ab ovo krónikus inflammációs folyamatok is. A specifikus immunválasz a bélrendszerben az IgA-termelésben mutatkozik. Az IgA-termelés nem adekvát volta esetében dysbacteriosis vagy közvetlen lokális infekció után az immunológiai elhárító válasz nem mindig tökéletes és ilyenkor a krónikus inflammatio perzisztál a májban, ami mindig fibrosissal jár. Vannak eleve krónikus jellegú vagy sikertelen heveny védekezés kapcsán kialakult, esetleg észrevétlen heveny kezdettel bíró májfolyamatok, fibrosisok $[5,7,8]$.

Korábban a szervezetnek a patológiás folyamatokkal kapcsolatos védekezését az elsődleges és másodlagos immunrendszerre felosztott immunrendszer feladatának tekintették. A mindmáig összegyúijtött, rendszerezett ismeretek birtokában bizonyossággal elmondható, hogy a májszövet is egyedi funkciókkal rendelkező immunszövetnek tekinthető. A metabolikus szereppel együtt az individuális immunológiai szerep osztályozása nehézkes.

\section{Akutfázis-reakció szindróma}

A szervezetet szakadatlanul érik kisebb-nagyobb sérülések, károsodások. Ezek egész serege szedhetô sorba. Mechanikus, hő-hideg hatás, kórokozók, toxikus anyagok okozhatnak ártalmat, metabolikus károsodások érhetik a szervezetet. A létrejött károsodások felismerése, elhárítása és reparációja az egész organizmus egyetemleges feladata. A törzsfejlődés folyamán olyan rendszerek alakultak ki, amelyek „hivatásszerúen” a szervezeti védekezést szolgálják. A felismerést, elhárítást, a restitúciót az immunrendszer szolgálja. Ennek fejlődéstanilag két, egymással összekapcsolt „szárnya” van. Az egyik a nem specifikus vagy naturális, a másik a specifikus vagy adaptív immunválasznak felel meg. A felismerési, elhárítási válasz alapvető formái, módozatai tartalmi vonatkozásokban rokoníthatók a különböző szöveti károsodásokban. Ezen folyamatokban a máj is mindig, elkerülhetetlen módon részesedik $[9,10,11]$.

Bakteriális fertőzést követően, ha a kórokozó be sem jut a keringésbe, lokális és általános elhárító válasz kerekedik. A májban csak a károsodott szövetból származó közvetítő jelek, szerkezetek odajutásával indulhat be a válaszreakció. Ha a kórokozó bejut a vérbe (szepszis), úgy a máj is késedelem nélkül, azonnal válaszkész lehet. Beindul az úgynevezett nem specifikus, naturális immunválasz, de ettól elválaszthatatlanul a specifikus vagy adaptív immunválasz is aktiválódik.

A naturális immunválasz módja, formája az úgynevezett APRS-szindróma. Ennek szomatikus és humorális 
jelei ismertek. A sérülés helyén Mo/Ma sejtek, granulocyták, mastocyták, ly-k aktivizálódnak. Kemokinek és citokinek sokasága képződik és alkot hálózatszerü struktúrát. A legkorábbi citokinek az interleukin-1 (IL-1), a tumornekrózis-faktor- $\alpha$ (TNF- $\alpha)$, az interferon- $\gamma$ $(\mathrm{IFN}-\gamma)$ és a TGF- $\beta$. Ezek bejutnak a vérkeringésbe, és így az egész szervezet, minden szerv mozgásba lendül. $\mathrm{Az}$ elsődleges citokinek másodlagos citokinek (IL-6, IL-4, IL-8) termelődését serkentik. Az IL-6 sejt membránreceptorának fó alkotórésze a GP130 szignáltranszduktor, amely a vérben is jelentős koncentrációt érhet el. Sokféle sejtben előfordul és a TGF- $\beta$ „segítsége” nélkül is felszabadulhat. Az IL-6-on kívül az IL-6 családtagok mind kötődnek a GP-n keresztül. Az IL-6 családtagok a leukaemiainhibitor-faktor (LIF), az IL-1 1, az onkostatin $\mathrm{M} / \mathrm{OSM}$, a ciliary neurotrophicus faktor (CNF), a cardiotrophin (CT), továbbá a glükokortikoidok, az epidermal growth factor (EGF), a hepatocyta growth factor (HGF), az IL- 8 , az IFN- $\alpha$ és - $\beta$, az IFN- $\gamma$ és természetesen az IL-6. Ezek különböző szövetekben képződnek. Főbb források gyanánt a Mo/Ma-k, elsősorban a máj Kupffer- és D-sejtjei említendőek. Ez utóbbiak szoros anatómiai közelségben helyezkednek el a hepatocytákkal. Azonban nem ez a fó ok, ami magyarázná, hogy az APR zömét termelik. A citokinek, APR-ek nagy mennyiségben fellelhetőek a keringésben. A cortex-hypothalamus-hypophysis-mellékvese tengely axis összehangolva irányítja a citokintermelést. Ebben a folyamatban az APR-ek a szervezet minden szövetét, tevékenységét öszszehangolva épülnek be az egységes szervezeti válasz formálásába. Ezen folyamatok a megfelelő klinikai tünetekkel együtt jelenítik meg a szervezet nem specifikus válaszát. A humán szérumban koncentrációváltozásokkal járó anyagok terebélyes sora lelhető fel. Idesorolandók a már említett APR-ek mellett a komplementrendszerkomponensek, lectinek, pentraxinok, a koagulációs-fibrinolitikus apparátus alkotóelemei, fémkötő molekulák, proteinázok és inhibitorok.

Az APR-ek szerepe meghatározó a gyulladásos válasz minden szereplőjének aktiválásában, a teljes restitúcióban. Korábban akkor beszéltünk APR-ról, ha a vérbeli koncentráció az inflammatio során minimum 25\%-kal módosult. Az emelkedő koncentrációt mutatók pozitív, míg a csökkenők negatív jelzőt kaptak. A plazmaalkotórészek soráról derült ki, hogy inflammatio során jelentős koncentrációváltozást mutatnak. A mennyiségi meghatározás kissé önkényes, és az irányváltozás jelenthet megválaszolandó kérdéseket $[11,12,13,14]$. A valóságban alig van olyan plazmakomponens, amelynek mennyisége mozdulatlan maradna. A C-reaktív protein (CRP-) szintben a változás mellett az „egészséges” szint megjelölés problematikus. Az $\alpha 2$-macroglobulin $(\alpha 2 \mathrm{M})$ például a Homo sapiensben csak mérsékelt emelkedést mutat, mégis fontos, tevékeny része van az akut és krónikus inflammatióban egyaránt. Az egyes funkciók a tényezők esetében nagyrészt ismeretesek, döntő szerepe a megítélésben a szervezeti egyetemleges hatásnak van. Ez pedig a szer- vezetet, annak épségét ért károsodás gyors felismerésében, elhárításában, a sérülés gyors helyreállításában rejlik, ha lehetséges a teljes restitutio ad integrum. Ismeretes, hogy az elhárító válasz (lokális és általános) eredményessége változó. A kiváltott válasz sokszor inadekvát a kórokozóval szemben, a sérülés/károsodás rendkívül széles határok között mozoghat, tartóssá válhat, esetleg letalis a kimenetel. Igen fontos, hogy az APR-ek döntő hányada, néhány kivételtől eltekintve, szerkezetileg GP. $\mathrm{Az}$ oligoszacharidok mennyisége, összetétele igen változó. Az orosomucoid molekuláris tömegének 40\%-a oligoszacharid, de vannak ennél sokkal kisebb oligoszacharidtartalmú tagok (IgG-molekulában mindössze néhány százalék). A leggyakoribb szénhidrát-molekulák a hexóz (galaktóz, mannóz), hexozamin és a sziálsavak $\mathrm{N}$-acetil- és N-metil-derivátumok [12]. A sziálsav az oligoszacharid-láncon mindig terminális pozícióban található, ami az aktivitást, felismerést és metabolizmust érinti. Az APR-ek koncentrációváltozásai szélsőséges határok között mozognak. Különösen feltűnő, hogy az akár ezerszeresére emelkedő CRP és amyloid-A éppen nem GP-szerkezet. Változások vannak a rendkívül gyors (órák: orosomucoid, CRP) és késóbbi (haptoglobin, al-antitripszin: 24 óra) változást mutatók tekintetében. A koncentrációesés is lehet meredek, zuhanásszerú (CPR, aAA) és lehet elhúzódóbb (24 óra). A hepcidinkoncentráció-emelkedés IL-1 és IL-6 hatására a kiindulási (alacsony) érték akár tízezerszeresére is lehetséges. Minden APR-nek van egyedi hatása, amely egymás viszonylatában erősítő, gátló jellegư és neutrális lehet. Az oligoszacharidok mennyiségi és minőségi, összetételbeli módosulásai is egyediek és jelentősek. A szintézis helye leggyakrabban a máj, azonban nemcsak a hepatocyták, hanem más sejttípusok is termelhetik (Mo/Ma, stellatasejtek, endothelium, fibroblast, myofibroblast stb.). TGFtermelődés és specifikus receptor szinte minden sejtféleségben előfordul.

A PG-molekulák szénhidrát-komponensei csak kisebb részben azonosak, a szerkezeti, nagyságrendi és elektromos töltésbeli vonatkozásban különböző szabályok érvényesülnek. A GP- és PG-molekulák általában negatív elektromos töltésűek, de a szóródás jelentôs. Az erôsebben negatív töltésüek, például a komplementkomponensek (C3, C4, C9, lectinek, collectinek, C1 inhibitor). Proteázhatást mutat például több APR. Így az al-antitripszin, $\alpha$ l-antikimotripszin, a pancreaseredetú szekrétoros tripszininhibitor, a ciszteinproteáz-inhibitor és az $\alpha 2 \mathrm{M}$. Ez utóbbi emberben nem számít APR-nek. A hepcidin a Fe-metabolizmust szolgálja a haemopexinnel együtt. A coeruloplasmin Ca-kötő, de vannak más ionkötő tagok. A koagulációs és fibrinolitikus hatásúak közé sorolható a fibrinogén, plazminogén, szöveti plazminogén aktivátor és inhibitor, a protein-S. Mindezek csak példákat jelentenek. A szekretált patogénfelismerők közé tartozik a CRP, az $\alpha \mathrm{AA}$, LPS-kötő protein, peptidoglikánokat felismerő proteinek és a szolúbilis CDl4. Sajátos funkciótulajdonos az $\alpha \mathrm{AA}$, az IL-1R-antago- 


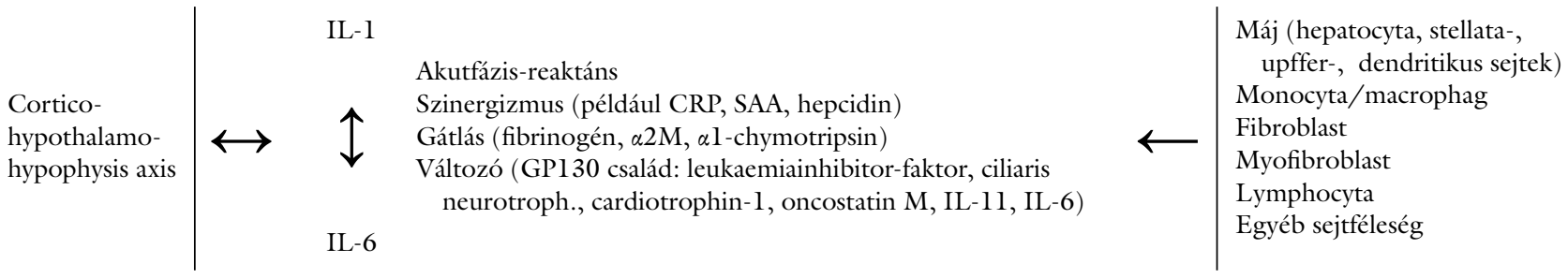

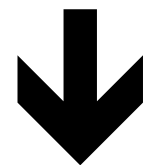

Antiinflammatio

nista, az angiotenzinogén és nem utolsósorban az orosomucoid ( $\alpha$ l-acid GP), ami szintén egyedi „csodabogár”. Oligoszacharid-láncai gazdagok sziálsavban. A felsoroltak között nem szerepel negatív APR. Idetartozik például az albumin, az $\alpha 2$ HS-GP (Heremans-Schmid) vagy a transzferrin, az inzulinszerü növekedési faktor (IGF), a XII. faktor, a transthyretin és a HDL. Az egyedi, fó hatások ritkán kizárólagosak. Egymás keletkezését, hatását, sorsát befolyásolva kifejtett együttes hatásuk a döntő (hálózatszerü makroszerkezet.) Egyértelmü, hogy a naturális immunrendszer, benne az APR-ek és az adaptív immunrendszer együttesen, az élő organizmus épségének megörzése mellett, a kárelhárítás letéteményese, azaz röviden az élő szervezet fennmaradásának szolgálója. Nem ritka, hogy az elhárító fázis, az inflammatio nem teljesen adekvát, az individuum vesztét is előidézheti (például szepszis). Ennek hátterében a károkozás, annak minősége, jellege, részben a védekezés nem „illeszkedő” volta, iránya, regulációs hiba húzódhat meg. Előfordul még congenitalis vagy szerzett immundefektus. A specifikus immunglobulinok kivétel nélkül GPszerkezetűek. Igen gazdag oligoszacharidokban az IgA (szekretoros) [13, 14, 15] (1. ábra).

A károsodás, az érintett helyból, esetleg a keringésből eredő substantia és az érintett szöveti sejtek (Mo/Ma, granulocyta, thrombocyta, ly) találkozása toborozza, aktiválja a védelem sejtjeit, amelyek a biológiailag aktív molekulák sokaságát produkálják. Ezek részben a helyszínen, részben generálisan hatnak. A sejtvándorlást különböző hatású kemokinek, citokinek, adhéziós molekulák, növekedési faktorok, hormonok képződése serkenti $[16,17]$.

A legfóbb citokinek egy csoportja, az IL-1, IL-6, TNF- $\alpha$ és TGF- $\beta$ egymás hatását jelentősen módosíthatják. Az IL-1 és TNF- $\alpha$ indukálja az IL- 6 keletkezését. Több APR IL-6 hiányában egyáltalán nem képződik. A GP130-hiány hasonló hatású. Az IL-6R inherens komponense a GP130, ami a keringésben is fellelhető szabadon. Az IL-1, TNF- $\alpha$, IL-6 és IFN- $\gamma$ meghatározó jelentôségű szeptikus sokkban, következményes sokszervi elégtelenséget okozva (citokinvihar). Az inflammatiót keltő kórokozók a patogénasszociált R-eken keresztül PAMP révén ismerhetők fel. Ezt követően transzkripciós faktorok aktiválódnak. Így például a signal transducer and activator of transcription (STAT) és/vagy molekuláris kappa-B/NFKB esetében aktivizálódik a STAT-responsive element (APRE) és suppressive cytokine signalling (SOCS). Fontos felismerő elemek a Toll-féle R-ek. A STAT szabályozza az APR-ek többségének a szintézisét, és meghatározó szereppel bír a CRP és az aAA képződésében. A STAT3 fontos eleme a p65 jelzésû partikulum, amely szükséges a teljes hatás eléréséhez, az úgynevezett inflammasomák kialakulásához. A lokális inflammatio az IL- 1, TNF- $\alpha$, IL- 6, IFN- $\gamma$ és TGF révén generalizálódik az inflammasomák közvetítésével. Megjelennek az ismert klinikai tünetek, corticotrop releasing factor, corticotrophin és glükokortikoidok keletkeznek többek között. Leukocytosis, lipid-, szénhidrát- és fehérje-anyagcserezavar lép fel, csökken a glükoneogenezis. A PAMP kialakulását követően PRR (pattern recognition $\mathrm{R}$ ) molekulák szekretálódnak, amelyek vagy membránhoz kötve, vagy intramolekulárisan helyezkednek el. Fô regulátorként az IL- $1 \alpha$ és - $\beta$, IL-6 rokon citokinek, APR-ek keletkeznek. A szervezeti elhárító, védekező válasz azonban centrálisan vezényelt. A transzkripciót követően transzlációs és poszttranszlációs módosulások jönnek létre. Különböző sejtek sokasága kapcsolódik be a folyamatokba. Különösen aktívak a máj Ma-k, amelyek az egész szervezetben fellelhető Ma-k 80\%-át reprezentálják. Elhelyezkedésük döntően a periportalis régió. Figyelembe véve a hepatocyták közelségét, azokkal együtt szerepük túlterjed a citokinképzésen. Az IL-1 inkább moderátorként képzelhető el, egyes APR-ek termelődését támogatva, gátolva vagy nem befolyásolva. Itt érdemes megjegyezni, hogy a különböző érési stádiumban levő granulocytákból és Ma-kból GP130, STAT3-aktivitást követően myeloid szuppresszor sejtek differenciálódnak, mobilizálódnak és szaporodnak fel a szövetekben. Ez a történés fontos a naturális immunválasz szabályozásában, amely még GP130-deficientia esetén is hatásos $[17,18,19,20]$ (1. táblázat). 
1. táblázat |Akutfázis-reaktánsok (vázlat)

\begin{tabular}{|c|c|}
\hline Tulajdonságok (funkcionális) & $\begin{array}{l}\text { Komplementrendszer-komponensek } \\
\text { Rövid petraxinok } \\
\text { Koagulációs, fibrinolitikus rendszer tagok } \\
\text { Proteázok (sokféle) } \\
\text { Phagocytaproteázok } \\
\text { Antiproteázok } \\
\text { Mintázatfelismeró receptorok (szolúbilis) } \\
\text { Scavangerfunkciós molekulák } \\
\text { Enzimgátlók } \\
\text { Transzportszerkezetek } \\
\text { Koleszterin, zsíranyagcsere-faktorok }\end{array}$ \\
\hline Multifunkciós & $\begin{array}{l}\text { STAT3-GP130 famíliatagok } \\
\text { Inflammációs faktorok } \\
\text { Sejtadhézió segítés-gátlás } \\
\text { Szöveti reparációs tényezők }\end{array}$ \\
\hline Regulátorok & $\begin{array}{l}\text { AP-reaktáns, IL-1, IL-6, IFN- } \gamma \text {, TGF- } \beta \\
\text { Citokinek } \\
\text { ACTH-mediált glükokortikoid termelés }\end{array}$ \\
\hline $\begin{array}{l}I L-1+I L-6 \text { gátlás } \\
\text { IL-1+IL-6 synerg. } \\
\text { Sejtnövekedés (differenciálás) } \\
\text { Legfőbb citokinek } \\
\text { Eredet }\end{array}$ & $\begin{array}{l}\text { Fibrinogén, } \alpha \text { l-chymotrypsin, } \alpha 2 \mathrm{M} \\
\text { CRP, SAA, haptoglobin, SAP, myeloid szuppresszor s. } \\
\text { TGF- } \beta \text {, VEGF, osteoprotegerin, bone morphogenetic protein, PDGF, FGF, CTGF, IL-6 } \\
\text { Il-1, IL-6, TNF- } \alpha \text {, TGF- } \beta \text {, IFN- } \gamma \\
\text { Hepatocyta, Mo/Ma, Kupffer-sejt, stellatasejt, fibroblast } \\
\text { Myofibroblast, egyéb sejt }\end{array}$ \\
\hline
\end{tabular}

Érdekes, jelenleg kissé még talányos a histidine-rich GP (HR-GP) molekula szerepe. A molekula tömegének 14\%-a oligoszacharid, és negatív APR-nek minősül. Molekuláris tömege 75 kD. Plazmabeli koncentrációja $\sim 145 \mathrm{mg} / \mathrm{dl}$. Fehérjeadaptor molekula, kapocsként szolgál két protein/GP molekula között. Multidomén szerkezetű, két ciszteinszerü régióval, puringazdag szakaszszal. A glandula parotisból előállítható egy körülbelül 50\%-os szekvenciaanalóg molekula. Humán vázizomból is kinyerhető egy mintegy $86 \mathrm{kD}$ tömegü hasonló molekula. A cystatin szupercsalád fó funkciója a cystatin gátlása. Kötődik $\mathrm{Zn}$ mellett más divalens kationhoz, továbbá protomyosin, plazminogén, thrombospodin, IgG, $\mathrm{Fc} \gamma \mathrm{R}, \mathrm{Clq}$, heparin, heparan-SO $\mathrm{O}_{4}$ molekulához adaptor molekulaként modulálja az immun-, vascularis és koagulációs rendszer múködését. Hepatocyták, Mo/Ma-k, megakaryocyták termelik. Szérumkoncentrációja meglepően csökken a graviditás harmadában, és alacsony pancreatitis acutában [21].

Az inter- $\alpha$-inhibitor egy „magányos” molekula. Humán plazmában változó a koncentrációja. Fellelhető thrombocytákban. Három láncból tevődik össze; két nehéz és egy könnyü láncból, a bikuninból. Antiproteolitikus hatással bír. Egy chondroitin $\mathrm{SO}_{4}$-lánc kovalens kötéssel kötődik hozzá. Az egyedüli, kivételes GP, amely poliszacharidláncot is birtokol. Az extracelluláris térben található. PCP-ben kimutatható a synovium fluidból. Hialuronannal kötődik. A nehéz lánc von Willebrand-faktort tartalmaz [22, 23].

Reprodukálható vizsgálatokkal igazolták, hogy a nagy HDL (high-density lipoprotein) molekula sok kisebb molekulát hordoz magában. Ez a tény önmagában meglepő; a befogadott legalább 48 molekula többsége APR. Találhatóak közöttük pozitív és negatív APR-ek; fellelhető például az orosomucoid, az $\alpha \mathrm{l}$-antitripszin vagy az 2 HS-GP. A HDL az atherosclerosiskutatás egyik központi alakja, a többi „ápolt” molekula különböző szerkezetű és funkciójú. Ezek együttesen teszik a HDL-t különleges molekulává, negatív APR-ré. Az egyedi funkcionális és összhatás azonban még ismeretlen [24].

\section{Tolerogén környezet a májban}

Az $\alpha 2 \mathrm{M}$ a humán szérum egyik makromolekulája. Molekuláris tömege $720 \mathrm{kD}$, jelentős oligoszacharidcsoportokkal, klasszikus GP. Négy identikus, 188 kD tömegű láncból áll. Minden láncon 5-5 aktív kötőhely található. „Rokonai” a komplement C3 komponense, a $\mathrm{C} 5$, valamint az úgynevezett pregnancy zone protein, homológ láncokkal. A molekula pan-proteináznak fogható fel. Funkciójában, szerkezetében jelentősen különböző molekulák sokaságával képes kapcsolatba lépni. A „bait” régió, ami 25 aminosavból áll, a láncok közepén helyezkedik el. A kapcsolódást követően molekuláris konformációváltozás észlelhető. A belső thiolészter lehasadása a konformációváltozás része. Feltűnő, hogy a humán szervezet összes $\alpha 2 \mathrm{M}$ mennyiségének $85 \%$-a a vascularis rendszerben található. A konformációváltozás csapdába ejti a proteázokat és szabályszerúen bezárja azokat, míg a kisebbeket, valamint az aktív centrumot és szubsztrátumokat nem. Ezek alapján beszélhetünk proteázgátlásról, amikor bezárul a proteáz aktív szakasza. 
Ez eltér más proteázok sorsától, amikor a komplex képződés együtt jár az aktív szakasz reverzíbilis gátlásával. A nem proteolitikus peptidek az $\alpha 2 \mathrm{M}$ csapdájába jutva védekezést szereznek exogén proteázok hatásával szemben. A proteázok okozta aktivált $\alpha 2 \mathrm{M}$ molekula kialakít egy „közbülső” $\alpha 2 \mathrm{M}$ molekulát. Az $\alpha 2 \mathrm{M}$ különös, körülbelül 550 millió éves szerkezetek árva tagja [25, 26, 27]. Az $\alpha 2 \mathrm{M}$ sajátos szerkezete révén a molekulák sorsa jelentősen különbözik. A kapcsolódás jelenthet hordozó szerepet, célba juttatást és inaktiválást. A Zn jelenléte és kötődése nem feltétele a proteáz csatlakozásának, de például az IL-1 kötődésének igen. Egyes molekulák bekebelezése azok tartós inaktiválását jelenti. A TGF kötődése után tartósan inaktív alakban marad. További sorsa nem tisztázott egyértelmúen. A kötődő citokinek egyik legfontosabbikának, az IL-6nak a bekebelezése fontos mozzanat. Az $\alpha 2 \mathrm{M}$-proteináz-komplexek gyorsabban eliminálódnak a kapcsolódást követően. Az a2M hepatocytákban, Mo/Ma sejtekben, astrocytákban, transzformált fibromyoblastokban képződik. Hepaticus stellatasejtekben a dexamethazon növeli a specifikus RNS mennyiségét. Humán idegsejtek a2M-szintézise IL-6-indukcióra jelentősen növekszik. Figyelemre méltó, hogy egyes tumorsejtek is képesek a2M-termelésre. Kérdés, hogy ez hogy függ össze a TGF-termelő képességgel. Melanomasejtek körülbelül egyharmadában nagy mennyiségben található. A koleszterin-anyagcserével is van kapcsolata. Koncentrációja a vérben graviditás alatt, embryogenesis idején és gyermekkorban megnövekedett. Ezen életperiódusokra a szervezet tömegének növekedése és intenzív differenciálódás jellemző. A low-density lipoprotein related protein (LRP) egyúttal az $\alpha 2 \mathrm{M}$ receptora is. Az LRP/ $22 \mathrm{M}$ 600 kD tömegü GP; a transz-Golgi-apparátusban proteolízist elszenvedve, nonkovalens kötésben alakul ki az 515+85 kD-os összetételű molekula. A GP komponens heparint és rokon PG-ket köt. Emberi plazmában a 40-50 közötti életévben éri el a $\sim 220$ mg/dl-es koncentrációt. Nőkben koncentrációja mindig nagyobb, és mintegy az 50-es életévekben kezd újból emelkedni. Emberben nem egyértelmű APR-ről van szó [28, 29, 30]. Receptora sokféle sejtmembránon, lymphycytákon is megtalálható. APRS-ben mennyisége csak mérsékelt emelkedést mutat a plazmában, nem úgy, mint például a fibrosis hepatis különböző stádiumaiban. Alkalmasnak tünik az inflammatio és a fibrosis követésére más paraméterekkel együtt (hyaluronan, TGF, kollagén), ami a klinikai gyakorlatban is felhasználható. A molekula oligoszacharidkomponensei jelentősek. Az oligoszacharidláncok végén mindig sziálsav található. Teljes hiányát emberben eddig mindössze 1-2 esetben lehetett bizonyítani. Csökkent plazmakoncentrációjának biológiai jelentősége homályos [30, 31]. Több mint 15000 humán szérum analízise során teljes hiányát magunk sem észleltük. Néhány esetben előfordult jelentősen csökkent koncentráció (maximum 50-60\%-os), felismerhető következmény nélkül. Kórosan alacsony szérumszint észlelhető akut pancreatitis és diffúz intravascularis coagulatio esetében $[31,32,33]$. Érdekes megfigyelés, hogy a PDGF és TGF- $\beta$ kötődnek a növekedési hormon receptorához, és gátlást idéznek elő anélkül, hogy a növekedési hormon koncentrációjában jelentős eltérés jelentkezett volna a fibroblastok felszaporodása és az a2M-termelés növekedése mellett [33]. Drogindukált hyperergiás vasculitis aktív szakaszában emelkedett az $\alpha 2 \mathrm{M}$-koncentráció és a CRP-szint. Hepatitits BV X antigén hatást vizsgálva TGF-aktivitás-fokozódás mellett az $\alpha 2 \mathrm{M}$-szint csökkent. Az $\alpha 2 \mathrm{M}$ megerősítést nyert ismérvei azt a nézetet támogatják, hogy az $\alpha 2 \mathrm{M}$ ősi védekezési rendszer tagjaként az egyed integritását, fennmaradását szolgálja. Máig megismert tulajdonságai azt mutatják, hogy segíti mind a specifikus, mind a naturális immunválasz folyamán a májban a tolerogén környezet kialakítását.

\section{A legfőbb szervező, a transzformáló növekedési faktor (TGF- $\beta$ )}

A TGF széles spektrumú, alapvető fontosságú, szabályozó citokin. Régebben felismert tulajdonságai mellett teljes funkcionális kapacitása máig sem ismert. Viszonylag kevés figyelem irányult az $\alpha 2 \mathrm{M}$ és a TGF kapcsolatára és ennek funkcionális következményeire. Szerepe a haemopoeticus rendszer szabályozása, a szervezeti perifériás immuntolerancia biztosítása. Szérumkoncentrációjában $(\sim 10 \mathrm{ng} / \mathrm{ml})$ viszonylag kis ingadozás regisztrálható. Kórokozó megjelenése esetén a szervezet védelmező, elhárító válaszának egyik letéteményese. Inflammatio kezdetén jelentős emelkedés észlelhető, elérvén a zenitet, a resolutio fázisban mérsékelt csökkenés, majd enyhe ingadozással újabb, jelentősebb csökkenés mutatkozik. A TGF- $\beta$ az egyik fó szabályozó citokin; sokféle tulajdonság birtokában a szervezet felismerő, elhárító és restitúciós folyamataiban egyaránt meghatározó szerepet birtokol sok millió év óta. A TGF- $\beta$ hatása Smad-faktorok (C. elegans: Sma+Drosophilam: mad együtt) közvetítésével receptorokon keresztül, jelek továbbításával szabályozza az immunválaszt [5]. A TGF- $\beta$ egy róla nevesített szuperfamília tagja a bone morphogenetic proteinekkel (BMP), activinekkel, növekedésidifferenciálódási faktorokkal együtt. Három megjelenési alakzata $(\beta 1, \beta 2, \beta 3)$ ismeretes; a TGF- $\beta 1$ a prominens forma, de hatásukban nincs lényeges különbség. A rendkívül bonyolult szintézis részletes ismertetése nélkül elmondható, hogy a latenciaasszociált protein (LAP) keletkezése után homodimer szerkezet képződik. Ez a latens alak. Ezt követően további lépések után komplex képződés révén egy latent TGF- $\beta$ binding protein (LTBP) jön létre. Ennek fontos szerepe van a mátrix felépítésében. Hőhatás, extrém pH-változás (az életben nem fordulnak elő), egyes proteázok révén módosul a molekula. In vivo proteináz hatásra (például transzglutamináz, $\alpha 2 \mathrm{M})$, továbbá thrombospondinnal való fizikai interakció, mechanikus vongálás, $\alpha \mathrm{v} \beta 6$ integrin hatására 
újabb szerkezetformálódás történik. Az aktiváció az epithelium-sejtmembránon teljesedik ki. A latens TGF aktiválása más enzimek hatására is bekövetkezik. Érdemes megemlíteni az N-glycanase, sialidase, neuraminidase hatásokat. Ezek révén a latens molekula oligoszacharidláncán a perifériás sziálsav lehasad, ami döntő momentum lehet. A géntranszkripció is bonyolult, jelentős részben feltáratlan. Bizonyosnak látszik citokinek részvétele a változásokban [33]. A három izomorf esetében transzlációs módosulás is történik [34]. A receptorok száma 35, de ebből 5-7 ismert teljesen. Erôs kötődés a membránon a TGFRIII. esetében betaglycan jelenlétében lehetséges. Így a betaglycan II. típusú receptornak is tekinthető. A szignalizációhoz Smad-proteinek szükségesek. Ezek között gátlóhatású is található [5]. A transzkripció után erősen kötődik a DNS-hez. A TGF kifejezett hatást gyakorol a T-lymphocytákra, de jelentősen módosítja a B-lymphocyta-funkciót is. Gátolja a sejtproliferációt, apoptózist indukál. Gátolja az immunglobulin-osztályok, -alosztályok be- és átkapcsolását, kivéve az IgA-t. Ebben több TGFR szuperfamíliatag szerepel. A per os és transnasalisan bejuttatott immunglobulinok esetében a TGF- $\beta 3$ jelenléte szükséges. Az IgA átkapcsolásához mindhárom TGF- $\beta$ alakzat jelenléte a feltétel. A TGF- $\beta$-hatások a T-lymphocyták esetében még döntőbbek. Gátlódik a sejtdifferenciálódás és -túlélés. Kostimulációs molekulák és gyulladásos citokinek módosíthatják a T-lymphocytákra gyakorolt TGF- $\beta$ hatást $[34,35]$. A T-lymphocytákra vonatkozó gátlóhatáshoz Smad 3 jelenléte szükséges, a leukocytagenezishez hasonlóan. Az INF-lymphotoxin, a Th2-citokin-termelődés hasonlóan csökken (Il-4, Il-5, Il-13). Ismeretes, hogy a Thl lymphocyták termelte citokinek a gyulladásos, autoimmun folyamatok, míg a Th2 citokinek az allergiás, atopiás folyamatok irányítói. Gátlódik a STAT4 transzkripciós faktor, míg az antiinflammatiós citokintermelődés növekszik. Az IL-9-expresszió-fokozódás a CD4 lymphocytákon jelentkezik. A cytotoxicus CD8 lymphocyták gátlásával az IFN- $\gamma$-expresszió csökken. Igen fontos a CD4+CD25 pozitív Treg (T-szuppresszió) sejtek redukciója. Ezekben TGF- $\beta$-hatásra Foxp3-pozitivitás és szuppressziós hatás érvényesül. Ezen sejtek a perifériás CD4+ lymphocyták 5-10\%-át teszik ki. A Th17 lymphocyták IL-23 jelenlétében termelnek IL-17-et. Natív T-lymphocyta-tenyészetben TGF- $\beta$ és IL-6 jelenlétében is termelődik IL-17 [36, 37, 38]. Megfelelő körülmények között IL-23 és IL-1 jelenlétében differenciálódás, Th17 lymphocytákká való elköteleződés érhető el. A TGF- $\beta$-hatás részben a sejtdifferenciálódás fokának a függvénye. A granulocyták és eosinophil sejtek egyaránt TGF- $\beta$-termelők, ami fibrosis kialakulásához vezethet. Az IL-5, amit a TGF- $\beta$ eosinophil sejtekben indukál, kritikus szerepet kap asthma bronchialéban. $\mathrm{Az}$ orális tolerancia tanulmányozása során ismerték fel a Th3-lympocytapopulációt, ami szintén TGF-termelő. Granulocytákban a TGF- $\beta 3$ predomináns. A natural killer sejtek a veleszületett immunrendszer alkotóele- mei. Védőszerepük van infekcióban, carcinomatosisban. Kemokineket, citokineket termelnek. Az IL-12 indukálta IFN- $\gamma$-elválasztás gátlásához Thl-aktivitás generálódik. Az NK-sejtek mind látens, mind aktív TGF- $\beta$ képzésre alkalmasak. Elősegítik dendritikus és rezidens Langerhans-sejtek keletkezését (epithelium, epidermis). A Langerhans-sejt-képződéshez E-cadherin és CDl lymphocyta jelenléte szükséges. A Mo-Langerhans-sejt átalakulás felgyorsul, a dendritikus sejteken MHCII és kostimulátor jelenik meg. Kritikus szerepük van a Ma-k általi sejtapoptózis kapcsán keletkező sejtalkatrészek eltakarításában. Az adhéziós molekulák, fibronectinreceptor megjelenése elősegíti a mátrixkapcsolatok képződését. A Mo/Ma átalakulás gátlódik, a scavanger funkció (például CD36-aktivitás) mérséklődik. Ma-k antigén-bemutatása is csökken. Gyulladásos citokin-kemokin gátlás érvényesül. A mastocytákban többek között serglycin, hisztamin, proteázok, TGF- $\alpha$ és - $\beta$ találhatók; utóbbiak felszabadulása fokozódik. A TGF- $\beta$ a mastocyták, granulocyták hatékony kemoattraktánsa. Csökken az E-szelektin, VCAM-felszabadulás az endotheliumról. Úgy tûnik, hogy a TGF támogatja a sejtmigrációt az inflammatio kezdetén, de a későbbi szakaszban inkább gátlóhatás érvényesül. A nem szignalizációs TGF- $\beta$ mellett PG-R-ek sokasága aktivizálódhat (például syndecan, fibroblastnövekedési faktor, p57 idegsejt-növekedési faktor). Az endotheliumon bőséggel található endoglin. Ennek hiánya esetén hereditaer haemorrhagiás teleangiectasia fordul elő. Nehezebben értelmezhető a TGF- $\beta$ szerepe daganatos folyamatokban. Általánosítva: kezdetben inkább gátló-, az előrehaladás során inkább serkentőhatások érvényesülnek. A TGF elősegíti az angiogenesist. Kiemelt szerepe van fibroticus folyamatokban [39, 40, 41, 42]. Szövettranszplantáció után az emelkedett TGF- $\beta$-koncentráció krónikus rejectiós szindrómát jelezhet. Hasonlóan eemlkedett TGF-ß-koncentráció jellemzi az invazív prostatacarcinomát, colorectalis daganatokat, vírushepatitiseket, graft versus host szindrómát, idiopathicus interstitialis pneumoniát és a krónikus peritonealis fibrosist. Nagyfokú TGF- $\beta$-hatás érvényesül az embryonalis fejlődésben és a sebgyógyulás folyamán. Tárolása inkább az extracelluláris mátrixban és a thrombocytákban történik. Feltünő, hogy TGF-termelésre csaknem minden sejt képes (immunsejtek, endothelium, epithelium, fibroblastok, neurocyták). Érdekes megfigyelés, hogy a tamoxifen megemeli a szérum-TGF- $\beta$-szintet. TGF- $\beta$ szükséges a Th17-elköteleződéshez hasonlóan az IL-6 és az adaptív immunaxis IL-2/Thl7 aktivitáshoz is $[43,44,45,46,47]$.

Összefoglalóan elmondható, hogy a TGF- $\beta$ különös egymásra utaltságban van a Langerhans-, Mo/Ma, T- és B-, a Treg- és NK-sejtekkel, ami alapját képezheti a szervezeti perifériás immuntolerancia fenntartásának. A Langerhans-sejt-képződéshez, valamint az IFN- $\gamma$ - és Ma-sejt-képződéshez Thl-stimulus szükséges. Az a2Mmel való korreláció (például az embryogenezisben) még nem feltárt. Különös tulajdonsága a TGF- $\beta$-nak, hogy 
extracellulárisan is aktiválható. Sajátos, hogy ezen tulajdonság $\alpha \mathrm{v} \beta 6$ és $\alpha \mathrm{v} \beta 8$ integrinek együttes aktivációját igényli, és így az érintett funkciók sokasága érvényesülhet az adaptív immunválaszban. Jelentős a TGF- $\beta$ szerepe autoimmun folyamatokban; a patológiás immunfolyamatok száma 70 körül lehet. A LED kialakulásában a T- és B-lymphocyták egyaránt részesednek. B-lymphocyta-hiperaktivitás és T-lymphocyta autoreaktív sejt klónok felszaporodása észlelhető. Diabetes mellitusban progresszív T-ly-k okozta pancreas- $\beta$-sejt-pusztulás mutatható ki. A primer krónikus polyarthritis T-lymphocyta-dependens, antitestmediált gyulladásos folyamat, amelyben elméletileg T-lymphocyta-gátlásra lenne szükség. A Th17- és IL-17-aktivitás döntő jelentőségü. Az atherosclerosis gyulladásos folyamat, ami ab origine, hullámzó fellobbanások mellett krónikus jelleget ölt. Bizonyos, hogy az oxidált LDL (low-density lipoprotein) -lerakódás, PG-khez való kötődés fontos mozzanatok a folyamatban. A laesióban IFN- $\gamma^{-}$, IFN- $\alpha$-, IL-8- és IL12 -felszaporodás észlelhető. Az IFN- $\gamma$-mRNS jelentősen felszaporodik. Kezdettől fogva egyedi, krónikus jellegű inflammatióról, vasculitisről van szó. A TGF- $\beta$ gátló jeleket közvetít váltakozó sikerrel. T-lymphocyta-gátlás a Ma-okra, továbbá a simaizomsejtekre és az endotheliumra irányulva a TGF- $\beta$-hatás eredménytelensége lehet. Kimutatható a CD36-, SR-A-, Ma-tevékenység csökkenése. A szérum TGF- $\beta$-tartalma csökken előrehaladott atherosclerosisban. Vírusinfekcióban a TGF regulátor szerepet kap. Vannak adatok felszaporodott TGF- $\beta$-ra vonatkozólag (influenza, $\mathrm{HBV}$-, $\mathrm{HCV}$-infekció). Influenzavírusok (A, B) direkt aktiválják a TGF- $\beta$ latens formáját neuraminidase GP-tartalmuk révén $[47,48,49]$. A hatásirányultságok sokasága az $\propto 2 \mathrm{M}$-mel karöltve azt eredményezi, hogy a májban a szervezet perifériás immuntoleranciája alakuljon ki. A rendkívül összetett folyamatban a TGF- $\beta$ a tolerogén környezet megteremtésében vesz részt. A tolerogén talaj kialakulásának a gyökerei már az intestinumban fellelhetők. A TGF- $\beta$ aktivátor integrinek, $\alpha \mathrm{v} \beta 6$ és $\alpha \mathrm{v} \beta 8$ közremúködése is fontos $[31,48,49,50]$.

\section{Fibrosis a májban}

A mesenchymasejtek az inflammatio elkerülhetetlen részesei. A Kupffer-sejtek, Ma-analógok tevékenysége általánosnak mondható minden hepatitises, gyulladásos folyamatban. A stellatasejtek aktivációja (amely két lépésben valósul meg), a proliferációs és fibrogenetikus citokinek termelődése és permanenssé válása meghatározó jelentőségü. A Mo-k felszaporodása a stellatasejtek aktivációját eredményezi. A stellatasejtek aktivációja TGF- $\beta$ hatására más sejtek aktivációjával társul (hepatocyta, lymphocyta és thrombocyta). A kóros Kupffer-sejtek a májban több phagocytált anyagot tartalmaznak, mint az ép szövetben jelenlevők. A stellatasejtek részt vesznek a vírus, baktérium, parazita okozta gyulladásos folyamatokban. A jelenség rokonítható a tüdő és a vese fibrotikus inflammatiójával, sőt az atherosclerosis folyamatával. Sajátos patogenezisú folyamat észlelhetó például haemochromatosisban. A fokozott hepatocytaapoptózis hasonló kiváltó tényező lehet. Nagy mennyiségben képződnek lipidperoxidok. A granulocyták, Kupffer-sejtek a mastocytákkal együtt különösen aktívak az inflammatio kezdetén. A stellatasejtek membránján R-ek tûnnek elő. Fontos esemény a PDGF-bekapcsolódás, legfóbb mediátor a TGF- $\beta$. Alkoholos eredetú májfolyamatokban bizonyos az acetaldehid károsító szerepe, de más etanolszármazékok is szerephez jutnak. A vírusoknak kiemelkedő jelentősége van a folyamat beindításában. Az inflammatio előrehaladását az interstitialis kötőszöveti elemek egyre fokozódó felszaporodása mutatja. Jelentős a kollagén rostok keletkezése. Legalább ötféle rostfajta keletkezik. A fibrillumképződést a rostok mennyiségi és minőségi megváltozása határozza meg. A rostképződés azonban a káros mátrixstruktúrakeletkezés kísérője $[49,50,51]$.

A steatosis hepatis, steatohepatitis és cirrhosis hepatis nagy fontossággal bírnak. A máj mikro- és makroszerkezetének átrendeződése észlelhető. A folyamatokban az $\alpha 2 \mathrm{M}$ és TGF- $\beta$ szerepe lényeges. A TGF az immunrendszer gátlása mellett az extracellulárismátrix-alkatók mennyiségi és minőségi változásait határozza meg. A PG-képződés és -depozíció, az összetétel átrendeződése progresszív fibrosis jellegúvé válik. A hepatocytapusztulást kötőszöveti struktúra helyettesíti. A folyamatok alakulását a TGF-polimorfizmus is színezi. A mátrix építőelemei között található PG-k a decorin, biglycan, heparan $\mathrm{SO}_{4}$, dermatan $\mathrm{SO}_{4}$, chondroitin $\mathrm{SO}_{4}$, továbbá a celluláris fibronectin, laminin, tenascin. Végül is megállapítható, hogy a fibroticus folyamatokban, az egyedfejlődésben, angiogenesisben és atherosclerosisban a mátrix szerkezeti átépülése során többször lelhetünk rokonítható folyamatokra. Egészségesekben a vér-TGF- $\beta$ koncentráció $10 \mathrm{ng} / \mathrm{ml}$ körül van. Májfibrosisban ab origine fel-felbukkanó inflammatio jelei lelhetőek fel. Úgy tekinthető, mint egy észrevétlen inflammatio, amely az első perctől kezdve krónikus jellegü és a hepatocytapusztulást az interstitialis kötőszövet burjánzása, szerkezeti átalakulása kíséri. Tehát az esetek döntő többségében fibrosisba torkolló, destruktív krónikus inflammatióról van szó. Általánosságban leszögezhető, hogy gyulladásos folyamat nélkül nincs fibrosis, és a kiváltó ok függvényében sok azonos, fibroticus folyamatot képező mechanizmus fordul elő $[52,53]$ (2. táblázat).

\section{Következtetések}

Az élő szervezet épségének, hibátlan múködésének biztosítása az immunrendszer feladata. Elsődleges és másodlagos immunszövetet szokás megkülönböztetni. A máj minősítése a rendelkezésre álló adatok, ismeretek birtokában nem egyértelmú. A májba jut a másodlagos lymphoid szövetből, a lépből és a mucosaasszociált (másodlagos) lymphoid szövetből származó vér. A saját 
2. táblázat | Fibrosissal járó gyakoribb kórfolyamatok

\begin{tabular}{ll}
\hline Cardiovascularis rendszer & Myelum, csontszövet, izület \\
Atherosclerosis & Polycythaemia rubra vera \\
Myocarditisek & Thrombocythaemia \\
Vitium cordis & Osteo-myelo sclerosis \\
Pericarditis (tbc) & Spondylarthritis ankylopoetica \\
Sarcoidosis & Polyarthritis chronica progressiva \\
Amyloidosis & Marfan-szindróma \\
Marfan-szindróma & Polychondritis relapsans \\
& Osteomyelitis \\
\hline Respiratorikus rendszer & Gastroenteralis rendszer \\
Sclerosis systematica progressiva & Gastroenteritis chronica \\
Egyéb autoimmun szindrómák & Enteritis regionalis \\
Pneumonitis chronica & Colitis ulcerosa \\
Asthma bronchiale & Coeliakia \\
Sarcoidosis & Scirrhus \\
Pneumonia & Irradiatio \\
Tbc pulmonum & \\
\hline Vese & Kötöszövet, bör \\
Glomerulonephritis & Sclerosis systhematica \\
Pyelonephritis & progressiva \\
IgA-nephropathia & Raynaud-szindróma \\
HIV-nephropathia & Dupuytren-contractura \\
Allograft-rejectio & Trauma, idegen test, sérülés (égés) \\
Fibrosis „retroperitonealis” & Keloidosis (savak, lúgok) \\
\hline Máj & Egyebek \\
Cirrhosis hepatis & Polyposis nasalis \\
Steatohepatitis & Peyronie-szindróma \\
Haemochromatosis & Psoriasis \\
Wilson-kór & Polymyositisek \\
Polycythaemia rubra vera & Fascitis eosinoph. \\
Amyloidosis & Irradiatio \\
\hline &
\end{tabular}

szövet és az egész organizmus integritása feletti őrködés a máj egyedi, különleges feladata. Egyedüli igen fontos saját tevékenysége mellett a szervezeti nem specifikus és szerzett immunológiai feladatokat lát el, karöltve az egész szervezettel. A szervezeti akutfázisreakció centrális résztvevője, a metabolikus folyamatok bonyolítója. Ezek mellett a szervezeti periferiális immuntolerancia kialakításának és fenntartásának a helye. Központi szerepe van a nem specifikus inflammatio, valamint a specifikus immunválasz regulációjában, a fenyegető, károsító behatások elhárításában, a létrejött organikus károsodás restitúciójában és ennek következtében a szervezeti perifériás immuntolerancia folyamatos fenntartásában. Ezekben a folyamatokban legf”ob „eszköze” a kiterjedt hatásspektrummal bíró TGF- $\beta$. A máj tehát a szervezeti metabolikus feladatok székhelye és egyedüli módon immunszöveti ténykedéseket végző orgánuma. Mindezt a szervezeten belül makroanatómiai lokalizációja, kapcsolatrendszere és egyedi szöveti felépítése teszi lehetővé. A sinusoidhoz hasonlítható szervi architektúra olyan sajátos (kettős) csatornarendszer, amelynek kialakulásában a hepatocyták mellett az egy sejtsoros endotheliumszerű struktúra (pericyták) és az azt körülölelő lipocyta (stellata, Ito-sejt) -tömeg, valamint az endotheliumszerű hártyán belül a Kupffer- és dendritikus sejtek sokasága alakít ki. Ez teszi lehetővé a kevert vena portae és arteria hepatica vér továbbítását a vena hepaticán keresztül a szisztémás keringésbe. Az említett és a most nem említett sejtes elemek alkotják a máj sejtes struktúráját, amely alkalmas az egyedi, sajátos feladatok elvégzésére. A szervezet fennmaradásának sine qua nonja a szöveti perifériás immuntolerancia, annak „hézag nélküli” ellátása. Szerepe nélkülözhetetlen mind a nem specifikus gyulladásos, mind a specifikus immunválaszban. A TGF a májszövettel karöltve úgy alakítja a szervezet számára szükséges baktériumflórát, hogy a védelem intakt maradjon a kórokozó tényezőkkel, sérülésekkel, károsodással szemben. A máj ugyanakkor a központi metabolikus folyamatok szabályozó központja, a nem specifikus és specifikus immunválasz nélkülözhetetlen résztvevője. Az organizmus olyan struktúrája, amely egyszerre metabolikus szerv és immunszerv. Az élő organizmus „táplálója” és védelmező őre egyszerre, egyedi módon.

Anyagi támogatás: A közlemény megírása anyagi támogatásban nem részesült.

A szerző a cikk végleges változatát elolvasta és jóváhagyta.

Érdekeltségek: A szerzőnek nincsenek érdekeltségei.

\section{Irodalom}

[1] Crispe, I. N.: The liver as a lymphoid organ. Annu. Rev. Immunol., 2009, 27, 147-163.

[2] Seki, E., Schnabl, B.: Role of innate immunity and the microbiota in liver fibrosis: crosstalk between the liver and gut. J. Physiol., 2012, 590(3), 447-458.

[3] Li, M. O., Wan, Y. Y., Sanjabi, S., et al.: Transforming growth factor-beta regulation of immune responses. Annu. Rev. Immunol., 2006, 24, 99-146.

[4] Friedman, S. L.: The cellular basis of hepatic fibrosis - Mechanisms and treatment strategies. NEJM, 1993, 328(25), 18281835.

[5] Travis, M. A., Sheppard, D.: TGF- $\beta$ activation and function in immunity. Annu. Rev. Immunol., 2014, 32, 51-82.

[6] Jakab, L.: Bone tissue: Rebuilding and inflammation. [Csontszövet: újdonképződés és inflammatio.] Orv. Hetil., 2014, 155(40), 1575-1583. [Hungarian]

[7] Border, W. A., Noble, N. A.: Transforming growth factor beta in tissue fibrosis. NEJM, 1994, 331(19), 1286-1292.

[8] Bottazzi, B., Doni, A., Garlanda, C., et al.: An integrated view of humoral innate immunity: pentraxins as a paradigm. Annu. Rev. Immunol., 2010, 28, 157-183.

[9] Bode, J. G., Albrecht, U., Häussinger, D., et al.: Hepatic acute phase proteins - Regulation by IL-6- and IL-1-type cytokines involving STAT3 and its crosstalk with NF- $\kappa \mathrm{B}$-dependent signaling. Eur. J. Cell Biol., 2012, 91(6-7), 496-505.

[10] Gabay, C., Kushner, I.: Acute-phase proteins and other systemic responses to inflammation. NEJM, 1999, 340(6), 448-454.

[11] Jakab, L., Kalabay, L.: The acute phase reaction syndrome: the acute phase reactants. Acta Microbiol. Immunol. Hung., 1998, 45(3-4), 409-418.

[12] Jakab, L.: Acute pancreatitis: inflammatory response of the body. [Pancreatitis acuta: A szervezeti inflammatoricus válasz.] Orv. Hetil., 1996, 137(39), 2141-2147. [Hungarian] 
[13] Kemper, C., Atkinson, J. P., Hourcade, D. E.: Properdin: emerging roles of a pattern-recognition molecule. Annu. Rev. Immunol., 2010, 28, 131-155.

[14] Häger, M., Pedersen, C. C., Larsen, M. T., et al.: MicroRNA-130amediated down-regulation of $S \operatorname{mad} 4$ contributes to reduced sensitivity to TGF- $\beta 1$ stimulation in granulocytic precursors. Blood, 2011, 118(25), 6649-6659.

[15] Jakab, L.: Acute phase reaction of the body. [A szervezeti „acut phasis reactio".] Orv. Hetil., 1993, 134(11), 563-568. [Hungarian]

[16] Ambrus, G., Gál, P., Kojima, M., et al.: Natural substrates and inhibitors of mannan-binding lectin-associated serine protease-1 and 2: A study on recombinant catalytic fragments. J. Immunol., 2003, 170(3), 1374-1382.

[17] Jakab, L., Jakab, L., Kalabay, L., et al.: The effect of the alpha 2-HS-glycoprotein on the mitogen-induced lymphoblastic transformation and IL-2 production. Acta Physiol. Hung., 1991, $77(1), 25-31$.

[18] Sander, L. E., Sackett, S. D., Dierssen, U., et al.: Hepatic acutephase proteins control innate immune responses during infection by promoting myeloid-derived suppressor cell function. J. Exp. Med., 2010, 207(7), 1453-1464.

[19] Benigni, F., Fantuzzi, G., Sacco, S., et al.: Six different cytokines that share GPI30 as a receptor subunit, induce serum amyloid A and potentiate the induction of interleukin- 6 and the activation of the hypothalamus-pituitary-adrenal axis by interleukin-1. Blood, 1996, 87(5), 1851-1854.

[20] Kekow, J., Reinhold, D., Pap, T., et al.: Intravenous immunoglobulins and transforming growth factor beta. Lancet, 1998, 351(9097), 184-185.

[21] Jones, A. L., Hulett, M. D., Parish, C. R.: Histidine-rich glycoprotein: A novel adaptor protein in plasma that modulates the immune, vascular and coagulation systems. Immunol. Cell Biol., $2005,83(2), 106-118$.

[22] Lamkin, E., Cheng, G., Calabro, A., et al.: Heavy chain transfer by tumor necrosis factor-stimulated gene 6 to the bikunin proteoglycan. J. Biol. Chem., 2015, 290(8), 5156-5166.

[23] Fries, E., Kaczmarczyk, A.: Inter-alpha-inhibitor, hyaluronan and inflammation. Acta Biochim Pol., 2003, 50(3), 735-742.

[24] Vaisar, T., Pennathur, S., Green, P. S., et al.: Shotgun proteomics implicates protease inhibition and complement activation in the antiinflammatory properties of HDL. J. Clin. Invest., 2007, $117(3), 746-756$.

[25] Fehér, J., Jakab, L., Szilvási, I., et al.: Concentration of various serum glycoproteins and serum immunoglobulins in chronic hepatitis and liver cirrhosis. Z. Gesamte Inn. Med., 1973, 28(14), 418-420. [Article in German]

[26] Fehér, J., Jakab, L., Szilvási, I.: Immunoglobulins, glycoproteins and Australia antigen in chronic liver disease. Acta Med. Acad. Sci. Hung., 1973, 30(3), 197-203.

[27] Ritchie, R. F., Palomaki, G. E., Neveux, L. M., et al.: Reference distributions for alpha2-macroglobulin: a practical, simple and clinically relevant approach in a large cohort. J. Clin. Lab. Anal., 2004, 18(2), 139-147.

[28] Tchetverikov, I., Verzijl, N., Huizinga, T. W., et al.: Active MMPs captured by alpha 2 macroglobulin as a marker of disease activity in rheumatoid arthritis. Clin. Exp. Rheumatol., 2003, 21(6), 711-718.

[29] Bode, J. G., Fischer, R., Häussinger, D., et al.: The inhibitory ef fect of IL-1 beta on IL-6-induced alpha 2-macroglobulin expression is due to activation of NF-kappa B. J. Immunol., 2001, 167(3), 1469-1481.

[30] Park, H. S., Kim, C. H., Kim, D. J., et al.: Diagnostic value of multiple biomarker panel for prediction of significant fibrosis in chronic hepatitis C. Clin. Biochem., 2011, 44(17-18), 13961399.

[31] Jakab, L., Pozsonyi, T., Fehér, J., et al.: Cell surface alpha2-macroglobulin of human lymphocytes. In: Peeters, H. (ed.): Protides of the Biological Fluids. Pergamon Press, Oxford and New York, 1978.
[32] Medzhitov, R., Janeway, C. Jr:: Innate immunity. NEJM, 2000, 343(5), 338-344.

[33] Borth, W.: Alpha 2-macroglobulin, a multifunctional binding protein with targeting characteristics. FASEB, 1992, 6(15), 33453353.

[34] Barnes, P. J., Karin, M.: Nuclear factor-kappaB: a pivotal transcription factor in chronic inflammatory diseases. NEJM, 1997, 336(15), 1066-1071.

[35] Lu, L. G., Zeng, M. D., Wan, M. B., et al.: Grading and staging of hepatic fibrosis, and its relationship with noninvasive diagnostic parameters. World J. Gastroenterol., 2003, 9(11), 2574-2578.

[36] López-Casillas, F., Payne, H. M., Andres, J. L., et al.: Betaglycan can act as a dual modulator of TGF-beta access to signaling receptors: mapping of ligand binding and GAG attachment sites. J. Cell Biol., 1994, 124(4), 557-568.

[37] Downing, J. R.: TGF-beta signaling, tumor suppression, and acute lymphoblastic leukemia. NEJM, 2004, 351(6), 528-530.

[38] Zhang, L., Esko, J. D.: Amino acid determinants that drive heparan sulfate assembly in a proteoglycan. J. Biol. Chem., 1994, 269(30), 19295-19299.

[39] Brúgós, B., Sebestyén, L., Pfliegler, Gy.: Inherited disorders of the connective tissues I. Pathomechanism and clinical characteristics of Marfan syndrome. [Öröklött kötőszöveti betegségek I. A Marfan-szindróma patomechanizmusa és klinikai jellemzői.] Immunológiai Szemle, 2014, 6(3-4), 59-65. [Hungarian]

[40] Ihn, H.: Pathogenesis of fibrosis: role of TGF-beta and CTGF. Curr. Opin. Rheumatol., 2002, 14(6), 681-685.

[41] Worthington, J. J. Czajkowska, B. I., Melton, A. C., et al.: Intestinal dendritic cells specialize to activate transforming growth factor $-\beta$ and induce Foxp $3+$ regulatory $T$ cells via integrin $\alpha \mathrm{v} \beta 8$. Gastroenterology, 2011, 141(5), 1802-1812.

[42] Kastelein, R. A., Hunter, C. A., Cua, D. J.: Discovery and biology of IL-23 and IL-27: related but functionally distinct regulators of inflammation. Annu. Rev. Immunol., 2007, 25, 221-242.

[43] Luo, B. H., Carman, C. V., Springer, T. A.: Structural basis of integrin regulation and signaling. Annu. Rev. Immunol., 2007, 25, 619-647.

[44] Pan, J., Clayton, M., Feitelson, M. A.: Hepatitis B virus X antigen promotes transforming growth factor-betal (TGF-betal) activity by up-regulation of TGF-betal and down-regulation of alpha2-macroglobulin. J. Gen. Virol., 2004, 85(2), 275-282.

[45] Blobe, G. C., Schiemann, W. P., Lodish, H. F.: Role of transforming growth factor beta in human disease. NEJM, 2000, 342(18), 1350-1358.

[46] Robertson, A. K., Rudling, M., Zhou, X., et al.: Disruption of TGF-beta signaling in T cells accelerates atherosclerosis. J. Clin. Invest. 2003, 112(9), 1342-1350.

[47] Davidson, T. S., DiPaolo, R. J., Andersson, J., et al.: Cutting edge: IL-2 is essential for TGF-beta-mediated induction of Foxp3+ T regulatory cells. J. Immunol., 2007, 178(7), 4022-4026.

[48] Lisnevskaia, L., Murphy, G., Isenberg, D.: Systemic lupus erythematosus. Lancet, 2014, 384(9957), 1878-1888.

[49] Lévesque, H., Girard, N., Maingonnat, C., et al.: Localization and solubilization of hyaluronan and of the hyaluronan-binding protein hyaluronectin in human normal and arteriosclerotic arterial walls. Atherosclerosis, 1994, 105(1), 51-62.

[50] Wrana, J. L.: Transforming growth factor- $\beta$ signaling and cirrhosis. Hepatology, 1999, 29(6), 1909-1910.

[51] Wick, G., Grundtman, C., Mayerl, C., et al.: The immunology of fibrosis. Annu. Rev. Immunol., 2013, 31, 107-135.

[52] Chodorowska, G., Czelej, D.: Drug-induced hyperergic vasculitis - activity of selected cytokines and acute phase proteins in plasma. Ann. Univ. Mariae Curie Sklodowska Med., 2003, 58(1), 43-47.

[53] Huang, S. S., Huang J. S.: TGF-beta control of cell proliferation. J. Cell. Biochem., 2005, 96(3), 447-462.

(Jakab Lajos dr., Budapest, Kútvölgyi út 4., 1125) 